\title{
SMALL CLAIM COURT : PRINCIPLE CONCRETIZATION IN LAWSUIT SETTLEMENT
}

\author{
Peni Rinda Listyawati \\ Sultan Agung Islamic University \\ penirinda@unissula.ac.id
}

\begin{abstract}
The purpose of this research is to examine the provisions of civil procedural law in settling a lawsuit, to know the form of simple, fast, and lowcost concretization in simple lawsuit settlement. The research method uses the research object of simple, fast, and low-cost concretization in the settlement of a simple claim, normative juridical approach, the type of data used in this study is secondary data, which is sourced from the literature. Secondary data consists of primary legal materials, secondary legal materials, legal material collection techniques carried out by literature and the internet, while the data analysis method is analyzed descriptively qualitatively. The results show that the provisions of civil procedural law in resolving claims in court so far have been using the basis of HIR, which do not differentiate between complicated and simple case examinations so that the time for settlement is the same. The process starting from submitting/registering a lawsuit, determining the day of trial by the head of the panel of judges, the parties being summoned appropriately, the trial, evidence to the verdict took a long time, namely 6 months (SUPREME COURT CIRCULAR No. 6 of 1992), so the Supreme Court issued SUPREME COURT CIRCULAR No. 2 of 2014 which provides a time limit for completing the case of five (5) months. The simple, fast, and low-cost principles of concretizing a small claim court can be seen in the settlement stage. Settlement of a simple lawsuit is divided into 4 (four) stages, namely: 1), preliminary stage, 2) stage of case examination, 3). The objection request stage and 4), the simple action decision stage. This simple lawsuit settlement process should take a maximum of 25 (twenty-five) days. The simple principle is embodied in the shortened settlement process mechanism, the fast principle is realized within 25 days of completion, a peace that does not use the provisions of Supreme Court rules No.1 of 2016, while the principle of low cost is realized from a simple settlement mechanism, will be affected by the cost of the case.
\end{abstract}

Keywords: Concretization; Cost; Lawsuit; Principle; Simple.

\section{A. INTRODUCTION}

In social life, humans interact with each other to make ends meet and also to socialize with each other. This social interaction often causes conflict. Sometimes this conflict can be resolved amicably, but sometimes the conflict creates constant tensions so that it needs a resolution involving other parties/competent institutions. Those who feel aggrieved can defend their rights by filing a lawsuit at the competent court. This is the state's way of protecting the human rights of its citizens, as stated in the text of the 
1945 Constitution, regarding the system of State Government, namely: "Indonesia is a country based on the law (Rechtsstaat), not based on mere power (Machstaat). Thus, one of the characteristics of a rule of law includes protecting the rights of its citizens. In addition, all community actions/activities are regulated by law with the aim of being orderly. Likewise, if a dispute occurs between the communities, it can be resolved through the court by way of suing.

Speaking about lawsuits, this is included in the realm of civil cases. In Indonesia, case settlement through courts or litigation is still the main choice. However, in its implementation, the courts are still ineffective and inefficient in examining and deciding cases so that the result is a buildup of cases in the Supreme Court. This accumulation should have been anticipated if the court applied the principles of fast, simple, and low-cost justice. This principle is the main principle in running the judiciary. Based on World Bank research, one of the inhibiting factors in resolving business disputes in Indonesia is: ${ }^{1}$ Inefficient first instance court dispute resolution; Long turnaround period; High court fees; High attorney fees, court-annexed mediation, which is usually conducted by a registrar and offers the advantage that it can be provided with little wait and at the court's expense, has become increasingly popular. ${ }^{2}$ Delay does more than deny justice. It has multiple cost implications, some more apparent than others. In commercial enterprise, for example, the uncertainty resulting from delay has both direct and incidental costs. Some of these will be measurable, and some not. ${ }^{3}$ Costs and delays are no longer to be matters for the parties alone to address. The wider community is seen to have a strong interest in promoting reasonably swift and economical dispute resolution and in conserving the scarce public resources required to administer the civil justice system. In short, timeliness and affordability are essential elements in justice. $^{4}$

Settlement of cases through courts is in fact not in accordance with the principles of fast, simple, and low cost contained in Act No. 48 of 2009 concerning Judicial Power which mandates the role of the court to assist justice seekers and strive to overcome all obstacles and obstacles to achieving justice which is fast, simple, and low cost.

The simple principle refers to a clear, easy-to-understand, and straightforward trial procedure. It would be better if justice seekers were faced with few and simple formalities for proceeding in court. However, the reality is that in society, there are still many justice seekers who do not understand the formalities of filing a claim for rights in court, which causes

1 Nevey Varida Ariani, Small Claim Lawsult in Indonesia Justice System, De Jure Legal Research Journal, Vol.18, No.3, September 2018, page 383.

2 James J Spigelman, Mediation and the Court, Law Society Journal, Vol. 39, No. 2, page 63

3 Chief Justice Michael Black, The Role of the Judge in Attaching Endemic Delays: Some Lessons from Fast Track, Journal of Judicial Administration, Vol. 88, No. 19, 2009, page 88,

4 Justice Ronald Sackville, The Future of Case Management in Litigation, Journal of Judicial Administration, Vol. 18, No. 211, 2009, page 212 
reluctance or fear to proceed in court. ${ }^{5}$ In practice, the simple principle is only interpreted as a mere administrative problem without the understanding that simple principles must become the spirit and motivation of law enforcers which is carried out comprehensively at every level and institution. ${ }^{6}$

The principle of speed refers to the operation of the judiciary. The fast running of the judiciary will increase the court's authority and increase public confidence in the courts. When compared with data from the Supreme Court, many civil cases have yet to be decided and eventually become a burden for the following year, this shows that settlement through the courts is still taking a long time. ${ }^{7}$ Whereas the principle of low cost so that it can be reached by the layers of society, high court fees mostly cause interested parties to be reluctant to file rights claims to the court. ${ }^{8}$

Recognizing this matter, the Supreme Court as a high institution implementing judicial power has issued Supreme Court Regulation Number 2 of 2015 concerning Procedures for Settlement of Simple Lawsuits, which has been amended by Supreme Court Rules Number 4 of 2019. This Supreme Court Regulation regarding this simple lawsuit was issued to speed up the process of solving cases following the principles of speed, simplicity, and low cost, considering that all this time the people who seek justice are still complaining about the lengthy litigation process in court. Given the importance of dispute settlement as the basis for legal certainty creation and justice, it needs regulations that empower the non-litigation civil disputes settlement based on local wisdom. ${ }^{9}$

A simple lawsuit or in popular terms is called a small claim court as regulated in Supreme Court rules Number 2 of 2015 which has been amended by Supreme Court rules No. 4 of 2019 is a civil dispute resolution procedure with certain conditions and restrictions with the aim of simplifying the process so that case settlement can be more fast. ${ }^{10}$ The quick settlement mechanism in this simple lawsuit is very beneficial for the community from the middle to lower classes to be able to submit a settlement of the dispute to the court. ${ }^{11}$ In addition, it is very beneficial for the business/trade world in the context of the ASEAN free trade era, which is likely to cause many small-scale commercial/business disputes that will end up in court. The issuance of this supreme court rules is an effort made by the Supreme Court to create a modern democratic state and improve the best services for the people who seek justice. Based on the description

5 Sudikno Martokusumo, 2010 Indonesian Civil Procedural Law, Atma Jaya University, Yogyakarta, page 47

6 Nevey Varida Ariani, De Jure Legal Research Journal, Volume 18, Number 3, September 2018, page 384.

7 Sudikno Martokusumo. Op. Cit. page 48.

8 Ibid., page 48

9 Uswatun Hasanah, Mohammad Amir Hamzah, Indien Winarwati, Development of NonLitigation Civil Dispute Settlement Model Based on Madurese Local Wisdom to Reduce Cases Accumulation in Court, Brawijaya Law Journal, , Vol. 6, No. 1,2009, page 116

10 Ridwan Mansyur and DY Witanto, 2017, Simple Lawsuit on Practice Theory and Its Problems, Pustaka Dunia, Jakarta, page 1

11 Ibid., page 2 
above, it is relevant to be the object of research which will examine the principles of simple, fast, and low cost which have been around for a long time (because it is one of the principles of civil procedural law), are concrete in the implementation through simple lawsuit settlement.

\section{B. RESEARCH METHODS}

The research method uses the research object of simple, fast, and low-cost concretization in the settlement of a simple claim, normative juridical approach, the type of data used in this study is secondary data, which is sourced from the literature. Secondary data consists of primary legal materials, secondary legal materials, legal material collection techniques carried out by literature and the internet, while the data analysis method is analyzed descriptively qualitatively. This study uses secondary data as analysis and is linked to relevant sources such as Supreme Court regulations and journals; related as secondary legal material.

\section{RESULT AND DISCUSSION}

\section{Civil Procedural Law Provisions in Resolving Lawsuits}

Civil procedural law is a legal instrument for solving cases for justice seekers. Talking about civil procedural law or formal law in Indonesia, it cannot be separated from the formation/birth of the HIR (Het Herzaine Indonesisch Reglement) which is one of the sources of law for judges to resolve cases that come to him. Starting from the Indonesian state colonized by the Netherlands, was Jhr. Mr.HLWichers, the Chief Justice of the Supreme Court and the Supreme Court of the Army in 1846 in Batavia had drafted an HIR on the orders/duties of the Governor-General (Gouverneur General) Jan Jacob Rochussen. The Draft Regulation deals with administrative law, police, civil procedures, and criminal procedures reserved for indigenous (Indonesian) groups. Within 8 months (announced on December 5, 1846, completed on August 6, 1847) the draft regulation could be completed by Jhr. Mr.HL Wichers, after experiencing additions to the proposal of the Supreme Court justices, the draft was accepted by the Governor-General and announced on 5 April 1848 with Stable. 1848 No. 16 with the title "Het Inlands Reglement" abbreviated as IR which came into effect on May $1,1848 .^{12}$

Het Inlands Reglement (HIR) has undergone many additions and changes since its implementation until 1941 (in Dutch it is called herzien) so that the contents of this IR are Staatsblad 1941 No. 44 renewed and hereinafter referred to as Het Herziene Inlandsch Reglement, abbreviated as HIR, means "Revised Bumiputra (Indonesia) Reglemen, which is abbreviated as RIB. This Dutch-made HIR, which has been enforced until now is regarding civil procedural law, while the regulations regarding police and criminal law are no longer enforced because Indonesia already has the Police Law and the Criminal Procedure Law as the work of the nation's children. Thus, to settle civil

12 Retnowulan Sutantio and Iskandar Oeripkartawinata, Civil Procedure Law in Theory and Practice, CV Mandar advanced, Bandung, 1997, page 7-8. 
cases in both district and religious courts, the formal law is based on HIR for Java and Madura, while outside Java and Madura uses RBg (Rechtreglement Buitengewesten).

As for proceedings in court according to HIR, a lawsuit or petition begins. A lawsuit is a claim for rights that contains a dispute so that there are two opposing parties, namely the plaintiff and the defendant. Meanwhile, the petition is a claim for rights that do not contain a dispute, meaning that there is only one applicant who submits an application to the court to determine, explain, confirm a legal condition or negate and create a legal situation. After the plaintiff registers, or submits the lawsuit in a competent court and the panel of judges appointed by the Head of the District/Religious Court determines the day of the hearing, the parties are summoned by the term appropriate/valid summons.

In the early stages of the trial, based on Article $130 \mathrm{HIR}$, the judge is obliged to reconcile the parties in a case (this is in accordance with the principle of an active judge). If the peace effort is successful, the court will issue a peace deed. According to Article 130 paragraph (3) HIR, this peace deed cannot be appealed. However, if there is no peace agreement, the trial will continue. According to Yahya, in practice, the effort to reconcile the parties is only a formality because Article 130 of the HIR is deemed not effective enough in reconciling the litigating parties and does not have a significant impact on the pile of cases in the Supreme Court. ${ }^{13}$ Based on the reality of the accumulation of cases (cassation) in the Supreme Court, this motivated the Supreme Court to make Supreme Court rules No. 1 of 2008 concerning Mediation Procedures in Courts, which has been amended by Supreme Court rules No. 1 of 2016. In addition to the reality of the accumulation of cases (cassations filed by the parties) in Supreme Court, Supreme Court rules Number 1 of 2016 is intended to provide greater access to the parties in a case to find satisfactory solutions and fulfill a sense of justice and are wrong a faster and cheaper dispute resolution process. So far it has provided opportunities for parties to resolve their problems by way of peace as regulated in Article 130 of the HIR, but in reality, it is less intensive, so it needs to be intensified by integrating the mediation process into the litigation procedure at the District Court.

With Supreme Court rules No. 1 of 2008, peace efforts are integrated into the court case settlement process, which is carried out at the beginning of the process through 2 (two) stages. The pre-mediation stage is that the parties are offered to choose a mediator, whether to use a mediator from the court or a mediator chosen by the parties (outside the court), as long as they have a certificate. Next is the mediation stage with the mediator that has been agreed by both

13 Muhammad Saleh and Lilik Mulyadi, Interest of Civil Procedural Law of Theoretical Perspectives, Practices and Problems, Alumni, Bandung, 2012, page 190. 
parties. At this stage of the mediation, the mediator tries to ensure that the parties can resolve the case in a peaceful manner, this mediation event is carried out no later than 30 days, counting since the stipulation of the order to conduct the mediation. If in this mediation program the parties agree to peace, then a Peace Deed (Acta van Dafing) and Stipulation on Claim Revocation will be made. However, if in the mediation event there is no agreement for peace, then a Decision will be issued to continue the Case Investigation. Judicial mediation is simply the next logical step in encouraging active case management practices. ${ }^{14}$

If the peace is not successful, then the trial is continued with the main examination of the case by the panel of judges which begins with the Lawsuit Reading Agenda, but in practice this case reading event is abolished, because the parties involved have received/held a copy of the lawsuit. The next agenda, the chairman of the panel of judges will ask the plaintiff or his attorney whether it remains with the lawsuit or will change the lawsuit, if the plaintiff states that it is still in the lawsuit, the trial will continue with the program for reading the answer by the defendant. The examination agenda after the Defendants' answers are answers or commonly referred to as duplicates.

There are two (2) substances of the answer put forward by the defendant, namely: 1). exceptions and 2). Straightforward answers to the subject matter. Exception is a refutation or objection from the defendant that does not cover the subject matter of the case, if successful, it can end the case in court. While the direct answer to the subject matter consists of 3 answers, namely:

a. confession, which means confirming the substance of the lawsuit;

b. rebuttal, namely statements that do not confirm or do not acknowledge what is being claimed;

c. referte, which leaves everything to the judge's discretion. If the process of presenting arguments or answers has been declared complete, then the next process is proof.

The Evidence stage in civil procedural law occupies a very important place, why is that? because civil procedural law or formal law aims to maintain and maintain civil material law. Thus formally the law of proof regulates how to provide evidence as regulated in the HIR. In civil procedure law, various types of evidence are regulated and the level of perfection of the evidence is regulated. Written evidence or letters are the most important evidence in civil cases, why? because civil law regulates the relationship between an individual or a person with a legal entity that starts with a legal relationship which is marked by an agreement. This agreement is made in writing, one of the purposes of which is to prepare it as evidence in the event of a dispute. In contrast to criminal cases, the main means of evidence is witness testimony. Why is that?, because someone who commits a criminal act always eliminates

14 David Spencer, Judicial Mediators: Is the Time Right?, Australian Dispute Resolution Journal Vol. 17, No, 6, page 130. 
written evidence or anything that allows the disclosure of the criminal act committed by the perpetrators. Therefore, evidence must be sought from the statements of people who happened to see, hear, or experience the incident themselves.

After the evidentiary stage considered, ie when both sides have finished filed evidence in a court of law, then the next stage of conclusion (conclusie), parties are given the opportunity to give the conclusion of the trial since the reading of the lawsuit until proof. In this case the judge can use the conclusions of the parties or ignore the conclusion, because at the end of the examination process, the panel of judges will make a conclusion in the form of a decision (judge's decision).

The judge's decision is the end of a series of process for examining a case. Before issuing a verdict, the panel of judges will deliberate to determine the actual legal relationship between the parties and what kind of decision will be passed. ${ }^{15}$ A $A$ judge's decision is a statement of a judge (panel of judges) which is written and pronounced in a trial open to the public which has the objective of resolving the dispute.

This series of civil case settlement processes takes a long time, it can be said that the time is unlimited. Settlement of civil cases which takes a long time is also not differentiated between complicated cases and simple cases, so that between complicated cases and simple ones, the settlement takes the same time. This of course does not reflect the principles of the trial, namely the principles of simple, fast and low court.

In practice, the time for the trial to examine a lawsuit in the court of first instance can take approximately 6 months. This time does not include the appeal examination (approximately 1 year) and cassation (approximately 2-3 years). This has not yet been counted by the lengthy execution process. Thus the application of the principle of justice is fast, simple and low cost "is only" a mere slogan, without reality. ${ }^{16}$ Based on this, the Supreme Court issued SUPREME COURT CIRCULAR No. 6 of 1992 which confirms that case examination (civil) at all levels of the judiciary is completed within a maximum period of six (6) months. On the way and to keep up with the development of SUPREME COURT CIRCULAR No. 6 of 1992 was amended by SUPREME COURT CIRCULAR No. 2 of 2014 which gave a time limit for completion of cases of five (5) months.

\section{Principle Small Claims Court in Action Settlement Fee Simple}

The settlement of a simple lawsuit is a new step in simplifying the mechanisms and procedures for resolving civil cases which are regulated through the Regulation of the Supreme Court of the Republic of

15 M. Natsir Asnawi, Civil Procedural Law, Theory, Practice and Problems in General Courts and Religious Courts, UUI-Press, Yogyakarta, 2016, page 475.

16 Arman Tjoneng, Simple Lawsuit as a Breakthrough of the Supreme Court in Resolving Case Stacking in Courts and Its Problems, Journal of Iuridical Dialogia. Vol.8 No.2 April 2017, page 97 
Indonesia Number 2 of 2015 concerning Procedures for Settlement of Simple Claims which have been amended by Regulation of the Supreme Court of the Republic of Indonesia Number 4 of 2019. This amendment was made to optimize the settlement of simple claims, especially in terms of the value of the material lawsuit, the jurisdiction of the plaintiffs and defendants, the use of electronic case administration, verzets, confiscation of guarantees, and procedures for execution.

The issuance of Regulation of the Supreme Court of the Republic of Indonesia Number 2 of 2015 (hereinafter typed by the Republic of Indonesia Regulation Number 2 of 2015) is a form of response from the Supreme Court in following the development of legal relations in the economic and other civil fields in Indonesian society in particular and in general the world community in the trade sector. In addition, the Supreme Court as one of the administrators of judicial power in Indonesia is given the authority by law to issue a regulation or regulation that functions as a legal vacuum or completes the lack of procedural law rules in order to keep up with developments in the trade sector as well as advances in technology and information that are better known as the industrial era 4.0.

The rapid development in the field of world trade and the development of information technology has changed the paradigm of society in various fields and will disrupt various human activities, including in the field of law, both in services, settlement methods and law enforcement activities.

In the field of law, the state has attempted to guarantee legal protection by providing various judicial institutions that function to resolve various legal problems. The existence of a judicial institution is intended as a means of facilities to uphold legal authority by providing access to justice for the disputing parties. ${ }^{17}$

With the spirit to keep abreast of developments in both the trade and information technology sector, the Supreme Court issued a Supreme Court rules regarding the simple lawsuit settlement procedure which is a manifestation of the implementation of the principle of procedural law, namely the principle of simple, fast and low cost. So far, the principles of simple, fast and low cost in practice have not been strictly implemented or can be said to be just a slogan. Investigation with a Short Procedure was actually known in Reglement op de Rechtsvordering but it was not enforced after Indonesian independence, with MA Jurisprudence No. 813 K/SIP/1976 through the Supreme Court Decision dated February 17, 1976, it was confirmed that Indonesian civil procedural law does not recognize express/brief examination. ${ }^{18}$

17 Benny Riyanto, Hapsari Tunjung Sekartaji, Empowerment of Civil Cases Simple Lawsuits to Realize Judiciary Implementation Based on Simple, Fast and Low Cost Principles, Journal of Legal Issues, Vol. 48 No. 1, January 2019, page 99.

18 Anita Afriana, Application of Short Events and Fast Procedures in Civil Dispute Resolution in Courts: A Political Review of Civil Procedural Law, Journal of Civil Procedure, Vol. 1 of 2015. 
Reglement op de Rechtsvordering (RV) is civil procedural law for European groups (in this case the Netherlands) which is included as a source of civil procedural law, meaning that judges can base it on RV if the case is not regulated in HIR. Why is that? because the judge may not reject a case that comes to him on the grounds that the law does not exist or is vague. With this provision, the judge is given the task to explore, discover, and interpret the law. In order to explore, find this law the judge can base on other regulations in this case can be based on RV or based on laws that live in the community. Before Indonesia's independence, it was known for brief case settlement based on this RV. However, it has not been enforced by MA Jurisprudence No. 813 $\mathrm{K} / \mathrm{SIP} / 1976$. Thus, in resolving civil cases so far based on HIR, the procedures are too rigid, formal and too technical, they should not be distorted, so it takes a long time for either simple cases or complicated cases.

The World Bank research, one of the inhibiting factors in resolving business disputes in Indonesia are: 1). Inefficient dispute resolution at court of first instance, 2). Long period of completion, 3). High court fees, 4). High attorney fees. ${ }^{19}$ On the other hand, the rapid and complex development of legal relations in the economic and other civil society fields requires a simpler, faster, and less costly dispute resolution procedure. This has been responded to by the Supreme Court, which in 2015 issued Supreme Court rules No. 2 of 2015 which has now been amended by Regulation No. 4 of 2019 concerning Amendments to Supreme Court Regulation No. 2 of 2015 concerning Procedures for Settlement of Simple Lawsuits.

Practical after the release of Supreme Court Rules No. 2 of 2015 which has been amended by Supreme Court Rules No. 4 of 2019 concerning Simple Lawsuit Settlement Procedures, this simple, fast and low cost principle can be realized. Changes to Supreme Court Rules No. 2 of 2015 to SUPREME COURT RULES No. 4 of 2019 because the settlement of a simple lawsuit received a positive response from the community in resolving disputes and seeking justice, so it is necessary to optimize the settlement of simple claims by perfecting Supreme Court Rules No. 2 of 2015, particularly in terms of the value of the material lawsuit, the jurisdiction of the plaintiff and the defendant, the use of electronic case administration, verzets, confiscation of guarantees and procedures for execution.

Before examining the stages of a simple lawsuit settlement process, we first understand what a simple lawsuit settlement is. Simple claim settlement is the procedure for examining a civil lawsuit with a maximum value of IDR 500,000,000 (five hundred million) which is settled by simple procedures and evidence (Article 1 paragraph (1) Supreme Court Rules No. 4 of 2019). A simple lawsuit is filed against a case of default and/or unlawful action with a maximum material claim

19 Nevey Varida Ariani, Simple Lawsuits and the Judicial System in Indonesia, DE JURE Legal Research Journal, Vol. 18 No.3, September 2018, page. 383. 
value of IDR 500,000,000, - (five hundred million rupiah). (Article 3 paragraph (1) SUPREME COURT RULES No. 4 of 2019). This simple lawsuit is included in the jurisdiction/jurisdiction of the general court (Article 2 SUPREME COURT RULES No. 4 of 2019), and not all cases can be resolved by filing a simple lawsuit, namely against cases where the settlement of disputes is carried out through special courts and disputes over land rights. (Article 3 paragraph (2) SUPREME COURT RULES No. 4 of 2019).

Civil lawsuit that can be categorized as a simple lawsuit as regulated in Article 3 and Article 4 SUPREME COURT RULES No. 4 of 2019 concerning Amendments to the Regulation of the Supreme Court Number 2 of 2015 concerning Procedures for Settlement of Simple Lawsuits, are:

a. Default disputes and/or unlawful actions with a maximum material claim value of IDR $500,000,000,-$;

b. These cases do not fall under the jurisdiction of special courts such as commercial disputes, industrial relations disputes and others;

c. Not a dispute over land rights;

d. The parties in a simple claim consist of the plaintiff and the defendant, each of whom may not be more than one, unless they have the same interest;

e. The residence of the defendant must be known;

f. The domicile of the plaintiff and the defendant must be in the jurisdiction of the same court;

g. If the plaintiff is outside the jurisdiction of the defendant's domicile, the plaintiff shall designate a power of attorney, incidental attorney or representative having an address in the defendant's jurisdiction with a letter of assignment from the plaintiff's institution;

h. Plaintiffs and defendants must attend in person each trial with or without being accompanied by a proxy, incidental attorney or representative with a letter of assignment from the plaintiff's institution.

The requirement for a case to be resolved through a simple lawsuit procedure is a dispute of default and unlawful action with a material claim value of a maximum of IDR $500,000,000$, -, which means that the default as referred to in Article 3 paragraph (1) arises from a loan agreement or default which is converted into an obligation to pay an amount of money. Likewise, the material for a lawsuit against the law that can be filed as a simple lawsuit is one that contains a claim for compensation of a maximum of IDR 500,000,000, - (five hundred million rupiah). If the case filed constitutes a particular form of action which is not related to the payment of a certain amount of money, then the plaintiff must convert the losses suffered into material losses in the form of a sum of money.

About the amendment of Article 4 is the insertion of 1 paragraph, namely paragraph (3a) which states that if the plaintiff is outside the jurisdiction of the defendant's residence or domicile, the plaintiff can 
appoint a power of attorney, incidental attorney, or a representative having an address in the defendant's jurisdiction. Whereas paragraph (4) was changed the editorial to the plaintiff and the defendant was obliged to directly attend every trial with or without the assistance of a proxy, incidental attorney or representative.

As for the concrete form of simple, fast and low cost principles starting from the stages of a simple lawsuit settlement process that has been regulated in Article 5 paragraph (2) SUPREME COURT RULES No. 4 of 2019 concerning Amendments to the Supreme Court Regulation Number 2 of 2015 concerning Procedures for Simple Lawsuit Resolution , that is :
a. registration
b. simple lawsuit completeness check
c. appointment of a judge and appointment of a substitute clerk,
d. preliminary examination
e. determination of the day of trial and summons of the parties,
f. trial and peace hearings'
g. proof, and
h. decision.

Settlement of this simple lawsuit must be completed within 25 days from the day of the first trial (Article 5 paragraph (3) SUPREME COURT RULES No.4 of 2019 concerning Amendments to the Supreme Court Regulation Number 2 of 2015 concerning Procedures for Settlement of Simple Lawsuits). This has shown the principle of being simple, fast and low cost, because it has not gone through a process of duplicating or answering each other which takes a long time. This is because this simple lawsuit case is not designed as a dispute, but seeks a quick and simple solution to the legal problems faced by the parties. ${ }^{20}$

The simple lawsuit settlement process that has been regulated in Article 5 paragraph (2) SUPREME COURT RULES No. 4 of 2019 concerning Amendments to the Supreme Court Regulation Number 2 of 2015 concerning Procedures for Settlement of a Simple Lawsuit can be classified into 4 stages. namely: 21

In submitting a simple lawsuit, it is divided into 4 (four) stages,

a. Introduction Stage

This preliminary stage consists of:

1) Registration (Article 6)

A simple lawsuit is submitted to the Junior Civil Registrar's

Office by filling in the available forms containing the identity of

20 Sherly Ayuna Putri, Civil Dispute Resolution through a Simple Lawsuit Based on Supreme Court rules No.2 of 2015, Journal of Unpad, Community Service, page.2

21 Arman Tjoneng, Simple Lawsuit as a Breakthrough of the Supreme Court in Resolving Case Stacking in Courts and Its Problems, Dialogia Iuridica: Journal of Business and Investment Law, Volume 8 Number 2 April 2017, page 98, and adapted to the new SUPREME COURT RULES (SUPREME COURT RULES No. 4 year 2019). 
the plaintiff and defendant, a brief explanation of the sit of the case, and the plaintiff's demands and attaching proof of a legalized letter. According to Article 6A SUPREME COURT RULES No.4 of 2019 concerning Amendments to the Supreme Court Regulation No.2 of 2015 concerning Simple Lawsuit Resolution Procedures that the plaintiff and defendant can use case administration in court electronically (e-court)

2) Examination of Completeness of Simple Lawsuit (Article 7 and Article 8)

The clerk checks the file, whether this case meets the requirements of a simple lawsuit based on the provisions of Article 3 and Article 4 If the case falls within the scope of a simple lawsuit, then the lawsuit is recorded in a special register book for simple claims if the case does not meet the requirements of Article 3 and Article 4, then the lawsuit file is returned to the plaintiff. The plaintiff is obliged to pay a down-payment of the court fee determined by the head of the court, but if the plaintiff is unable to file a proceedings on a prodeo basis.

3) Appointment of Judges and Appointment of Substitute Registrars (Articles 9 and 10)

In this case, the appointment of a single judge is carried out by the Chairman of the District Court, while the determination of the Substitute Registrar is made by the Registrar. The registration process for a simple lawsuit, the appointment of a judge and the appointment of a substitute clerk shall be carried out no later than 2 (two) days.

4) Preliminary Examination by Single Judge (Art. 11 and Art. 12)

The Sole Judge appointed by the Chairperson of the Court, examined the material of the Simple Lawsuit whether it met the requirements of Article 3 and Article 4 of SUPREME COURT RULES No. 4 of 2019 concerning Amendments to the Supreme Court Regulation Number 2 of 2015 concerning Procedures for Settlement of Simple Lawsuits, and assessed whether the evidence of the lawsuit was simple or not. If the judge considers that the lawsuit is not Simple Lawsuit, then the judge issues a Stipulation stating that the lawsuit is not Simple Lawsuit and the Clerk of the Court removes the case from the register and orders the return of the remaining costs of the case to the plaintiff. There is no legal remedy for this determination. However, if the judge considers the lawsuit to be a simple lawsuit, the judge determines the day of the first trial.

b. Principal Case Examination Stage

At this stage, consisting of:

1) Summons and Attendance of the Parties and the role of the Judge (Article 13 and Article 14)

If the plaintiff is not present on the first trial day without valid reasons, then the claim will be declared null and void. If the 
defendant is not present on the first trial day, a second proper summons will be made, but if the defendant is not present on the second trial day, the judge will decide in verstek (decision without the defendant's presence).

Regarding the verstek decision, the defendant can file a challenge (verzet) within a grace period of 7 (seven) days after the notification of the verdict. (Article 13 paragraph (3a). If the defendant is present on the day of the first trial and does not appear at the following sessions without valid reasons, then the lawsuit is examined and decided contradictory. Regarding the decision as referred to in paragraph (3a) and the contradictory decision, the defendant can file a In presiding over a hearing attended by the parties, the Judge is obliged to provide an explanation of the simple lawsuit in a balanced manner to the parties, strive for a peaceful settlement of the case including advising the parties to make peace outside the trial, guiding the parties in proof, and explaining legal remedies that can be taken by the parties.

2) Peace (Article 15 and Article 16)

The first day of trial, the judge is obliged to strive for peace that deviates from the mediation process regulated in SUPREME COURT RULES No. 1 of 2016, if peace is successful, the judge will make a Peace Deed Decision which binds the parties, and against this decision any legal remedy cannot be filed. If the reconciliation is carried out outside the court and is not reported to the judge, the judge is not bound by the peace. In the event that peace is not achieved, the trial will continue with the agenda of reading the lawsuit and the answers of the defendants.

3) Principal Examination of Cases (Article 17 and Article 18)

The main examination the case is marked by the reading of the Plaintiff's "lawsuit" followed by the Defendant's answer. (Article 16). In a simple lawsuit, claims for provisions, exceptions, reconventions, interventions, duplications, and conclusions cannot be filed (Article 17). In the process of examination, the judge may order the placement of collateral confiscation of the property of the defendant and/or the plaintiff which is under the control of the defendant. (Article 17 A). Furthermore, the argument of the lawsuit which is unanimously acknowledged by the defendant, does not need additional evidence (Article 18 of Supreme Court rules no.4 of 2019). Regarding the argument of the lawsuit that is denied, the judge conducts an examination of evidence based on the applicable procedural law.

4) Verdict (Article 19 and Article 20)

The verdict is read out by the judge at an open court to the public, consisting of the head of the verdict with a message that reads: "For Justice Based on Almighty Godhead", the identity of 
the parties, a brief description of the sit of the case, legal considerations, and the verdict. In the event that the parties are not present, the bailiff will notify the verdict no later than 2 (two) days after the verdict is pronounced. The judge is obliged to inform the parties' rights to object to the judge's decision.

c. Objection Modeling Stage (Article 21 and Article 22)

The legal remedy against the simple lawsuit decision is to file an objection.

1) Registration of Application for Objection

Objections are submitted to the Chief Justice of the District Court no later than 7 (seven) days after the decision is read by signing the Deed of Objection Statement before the clerk with the reasons and filling out the form for Objection Application. The Registrar's Office receives and checks the completeness of the Objection Application file accompanied by a Memory of the Objection made by the Objection Applicant. Subsequently, notification of objection and Memorandum of Objection is submitted to the Objection Respondent within 3 (three) days of receipt of the objection request. Meanwhile, the Objection Respondent submits a Counter Memorandum of Objection to the Head of District Court no later than 3 (three) days after the notification of objection

2) Objection Check

After the Application for Objection is declared complete, the Head of the District Court determines the panel of judges to examine and decide on the Objection application. Furthermore, the panel of judges conducts an examination of objections on the basis of the verdict and lawsuit file, application for objections, memory of objections and counter memory of objections. In this simple suit, the judge does not carry out additional examinations, in contrast to the appeal (ordinary procedure) in the High Court which can still carry out additional examinations if there is still a deficiency.

3) Objection Verdict

The decision on the Application for Objection is pronounced no later than 7 (seven) days after the date of the decision of the panel of judges by the Chairman of the District Court. This decision must be notified to the parties no later than 3 (three) days after the decision on the Application for Objection is made, and this decision cannot be taken as legal remedies, because the decision on this Application for Objection has Supreme Court legal force.

d. Stage of Implementation of Simple Claims Award

The simple lawsuit verdict which has Supreme Court rulesnent legal force, is implemented voluntarily. Furthermore, the Chairman of the Court issues an aanmaning decision no later than 7 (seven) days after receiving the letter of request for execution (Article 31 
paragraph (2a) of Supreme Court rules No.4 of 2019). The Chief Justice determines the date for the implementation of the aanmaning no later than 7 (seven) days after the appointment of the aanmaning. (Article 31 paragraph (2b) of Supreme Court rules No.4 of 2019). In certain geographic conditions, the implementation of aanmaning cannot be carried out within 7 (seven) days, the Chief Justice may deviate from the time limit stipulated in paragraph (2b) (Article 31 paragraph (2c)). If the decision is not obeyed, the decision will be carried out based on civil procedural law, namely through court assistance to execute.

Observing the 4 stages in the simple lawsuit settlement process, it can be seen that the realization of the simple, fast and low cost principles as mandated in Act No. 48 of 2009 concerning Judicial Power which in Article 2 paragraph (4) states that the trial is carried out simply, quickly and low cost. This principle is a fundamental principle in the implementation of administrative services in court that realizes effective and efficient services, one of which is manifested in electronic-based administrative services (e-court), as well as simple, straightforward formalities.

If we look at the Simple Lawsuit mechanism, it is very clear that there is a significant "simplicity" compared to the ordinary lawsuit, where in the Simple Lawsuit filing it is not necessary to make a complicated lawsuit like ordinary lawsuits, it is enough to describe the case position and the evidence contained in the form provided and there is no need to submit exceptions, replications, duplicates, demands for provisions, reconstructions, interventions and conclusions. In addition, the objection mechanism to the decision of the simple suit does not recognize any remedy for appeal, cassation, and review. ${ }^{22}$

The principle of speed, manifested in the simple lawsuit settlement process of no later than 25 (twenty five) days from the first trial day, the peace agenda does not use the provisions of SUPREME COURT RULES No.1 of 2016, and is also seen in the simplified process stages, it will automatically take effect at the same time needed to settle a simple lawsuit. Meanwhile, the principle of low cost is manifested in limited parties, a short trial mechanism, the parties in the same jurisdiction as the court, of course, will be affected by the cost of the case.

\section{CONCLUSION}

Civil procedural law is a legal instrument for solving cases for justice seekers. In Indonesia, the formal legal basis for resolving civil cases in court is the Het Herziene Reglement (HIR) which is carried out with a process that does not differentiate between the object value of the lawsuit and whether

22 Arman Tjoneng, Simple Lawsuit as a Breakthrough of the Supreme Court in Resolving Case Stacking in Courts and Its Problems, Dialogia Iuridica: Journal of Business and Investment Law, Volume 8 Number 2, April 2017, page.102 
evidence is simple or not, so that between a simple lawsuit and a complicated lawsuit both take a long time. The process starting from submitting/registering a lawsuit, determining the day of trial by the head of the panel of judges, the parties being summoned appropriately, the trial, the evidence until the verdict takes a long time. Based on this, the Supreme Court issued SUPREME COURT CIRCULAR No. 6 of 1992 which confirms that case examination (civil) at all levels of the judiciary is completed within a maximum period of six (6) months. On the way and to keep up with the development of SUPREME COURT CIRCULAR No. 6 of 1992 was amended by SUPREME COURT CIRCULAR No. 2 of 2014 which gave a time limit for completion of cases of five (5) months. The embodiment of the principles of simple, fast and low cost in the settlement of this small claim court is seen in Article 5 SUPREME COURT RULES No. 4 of 2019 concerning Amendments to the Regulation of the Supreme Court Number 2 of 2015 concerning Procedures for Settlement of Simple Lawsuits, which can be detailed in 4 stages, namely 1 ). preliminary stage, 2 ). Principal investigation stage of the case, 3). The objection request stage, 4). The implementation stage of the lawsuit decision is simple. The process for settlement of this Simple Lawsuit is no later than 25 (twenty five) days from the first trial day. The simple principle, embodied in the Simple Lawsuit mechanism, is that there is a significant "simplicity" compared to the ordinary lawsuit, where in the Simple Lawsuit filing there is no need to make a lawsuit, it is enough to describe the position case and the evidence contained in the form and there is no need to file an exception, replicate, duplicates, demands for provisions, conversions, interventions and conclusions. In addition, the objection mechanism to the decision of the simple suit does not recognize any remedy for appeal, cassation, and review. The principle of speed, manifested in the simple lawsuit settlement process of no later than 25 (twenty five) days from the first trial day, the peace agenda does not use the provisions of SUPREME COURT RULES No.1 of 2016, and is also seen in the simplified process stages, it will automatically take effect at the same time, needed to settle a simple lawsuit. Meanwhile, the principle of low cost is manifested in limited parties, a short trial mechanism, the parties in the same jurisdiction as the court, of course, will be affected by the cost of the case.

\section{BIBLIOGRAPHY}

\section{Books :}

Muhammad Saleh and Lilik Mulyadi, 2012, Ketertarikan Hukum Acara Perdata Perspektif Teoritis, Praktek dan Masalah, Alumni, Bandung;

M. Natsir Asnawi, 2016, Hukum Acara Perdata Teori Praktek dan masalah Peradilan Umum dan Peradilan Agama, UUI-Pre ss, Yogyakarta;

Retnowulan Sutantio and Iskandar Oeripkartawinata, 1997, Hukum Acara Perdata Teori and Praktek, CV Mandar advanced, Bandung; 
Ridwan Mansyur and DY Witanto, 2017, Teori Praktek Gugatan Sederhana dan Permasalahannya, Pustaka Dunia, Jakarta;

Sudikno Martokusumo, 2010, Hukum Acara Perdata Indonesia, Atma Jaya University, Yogyakarta;

\section{Journals :}

Anita Afriana, Application of Short Events and Fast Procedures in Civil Dispute Resolution in Courts: A Political Review of Civil Procedural Law, Journal of Civil Procedural Law, Vol. 1, No. 1, of 2015;

Arman Tjoneng, Simple Lawsuit as a Breakthrough of the Supreme Court in Resolving Case Stacking in Courts and Its Problems, Dialogia Iuridica: Journal of Iuridical Dialogia, Vol. 8 No. 2, April 2017;

Benny Riyanto, Hapsari Tunjung Sekartaji, Empowerment of Civil Cases Simple Lawsuits to Realize Judicial Administration based on Simple, Fast and Low Cost Principles, Journal of Legal Issues, Vol. 48 No. 1, January 2019;

Chief Justice Michael Black, The Role of the Judge in Attaching Endemic Delays: Some Lessons from Fast Track, Journal of Judicial Administration, Vol. 88, Number 19, page 88, 2009;

David Spencer, Judicial Mediators: Is the Time Right?, Australian Dispute Resolution Journal, Vol. 17, No, 6, 2006;

James J Spigelman, Mediation and the Court, Law Society Journal, Vol. 39, No.2, 2001;

Justice Ronald Sackville, The Future of Case Management in Litigation, Journal of Judicial Administration, Vol. 18, No. 211, page 212, 2009;

Nevey Varida Ariani, Simple Lawsuits and the Judicial System in Indonesia, $D E$ JURE Legal Research Journal, Vol. 18 No. 3, September 2018;

Sherly Ayuna Putri, Civil Dispute Resolution through a Simple Lawsuit Based on Supreme Court rules, Journal of Unpad Community Service. Vol. 8, No.2 of 2015;

Uswatun Hasanah, Mohammad Amir Hamzah, Indien Winarwati, Development of Non-Litigation Civil Dispute Settlement Model Based on Madurese Local Wisdom to Reduce Cases Accumulation in Court, Brawijaya Law Journal, Vol. 6, No. 1, 2019. Page 116;

\section{Regulations :}

Constitution of Indonesia of 1945

Act No. 48 of 2009 concerning Judicial Power

Het Herziene Indonesich Reglement

Supreme Court Regulation No. 2 of 2015 concerning Procedures for Settlement of Simple Lawsuits. 
Supreme Court Regulation No. 1 of 2016 concerning Mediation Procedures in Courts.

Supreme Court Regulation No. 4 of 2019 concerning Amendments to the Regulation of the Supreme Court Number 2 of 2015 concerning Procedures for Settlement of Simple Lawsuits.

Supreme Court Circular No. 6 of 1992 concerning Case Settlement in High Court and District Court.

Supreme Court Circular No. 2 of 2014 concerning Case Settlement in the First Level Courts and the Appeal Level in 4 (four) Judicial Environments. 